\title{
Industrially Contaminated Areas in Serbia as a Potential Public Health Threat to the Exposed Population
}

\author{
BRANISLAVA I. MATIĆ, Institute of Public Health of Serbia, \\ "Dr Milan Jovanović Batut", Belgrade \\ UROŠ D. RAKIĆ, Institute of Public Health of Serbia, \\ "Dr Milan Jovanović Batut", Belgrade \\ SNEŽANA M. DEJANOVIĆ, Institute of Public Health of Serbia, \\ "Dr Milan Jovanović Batut", Belgrade \\ VERICA S. JOVANOVIĆ, Institute of Public Health of Serbia, \\ "Dr Milan Jovanović Batut", Belgrade \\ MARIJA R. JEVTIĆ, University of Novi Sad, \\ Faculty of Medicine, Novi Sad \\ NELA Ž. ĐONOVIĆ, University of Kragujevac, Faculty of Medical Sciences, \\ Department of Hygiene and Ecology, Kragujevac
} Original scientific paper

UDC: 504.5:628.4.045 628.4 .045

DOI: 10.5937/tehnikal703441M

\begin{abstract}
Mining and mineral processing is still a vital source of income in Serbia, due to mineral abundance in copper, lead, zinc, antimony. Copper mining and metal-processing are located in the east: Bor, Veliki Krivelj, Cerovo, Majdanpek. Abandoned sites from antimony mining and processing and secondary lead smelter are at the western border: Zajača, Krupanj, Stolice. Coal mining and power plants are surrounding Belgrade: Obrenovac (2 power plants), Grabovac (plant ash landfill), Kolubara and Kostolac. Main objective is to focus on potential public health hazards from industrial contamination in Serbia. Key public health issue is presence of As and Cd in ambient air PM10 close to industrially contaminated sites due to the fact that ores have high naturally occurring contents of heavy metals and metalloids. Data originate from Serbian Environmental Protection Agency, Mining and Metallurgy Institute Bor, Belgrade Institute of Public Health, as part of continuous measurement of air quality within State network of automatic stations. Concentration of As in PM10 are extremely above the limit value in Bor and Lazarevac, with Cd values slightly increased in Bor. Serbia lacks the legal framework for continuous and institutionalized follow-up of population groups vulnerable to hazardous environmental exposure, although measured concentration indicate urgent need for such activities.
\end{abstract}

Key words: industrially contaminated sites, public health, $A s, C d, P b$

\section{INTRODUCTION}

The rapid growth of urbanization and industrialization, where the progressive expansion of the suburbs into closer proximity with industrial plants in certain areas, has led to the problem of air pollution [1]. As we know, human health is intimately connected to the surrounding environment. This is particularly the case of the health of people living in contaminated si-

Author's address: Branislava Matić, Institute of Public Health of Serbia, "Dr Milan Jovanović Batut", Belgrade, Dr Subotića starijeg 5

e-mail: damjanko98@yahoo.com

Paper received: 08.05.2017.

Paper accepted: 17.05.2017. te(s) (CS) which is affected by the legacy of past industrialization and current industrial activities, often in absence of environmental remediation [2]. Although main polluting sources may vary across Europe, industrial production and commercial activities, oil industry and waste disposal and treatment are reported to be the major ones. National reports indicate that heavy metals and mineral oils are the main soil contaminants, while mineral oils and chlorinated hydrocarbons are the most frequent pollutants found in groundwater [3].

The term CS can have different meanings. A general definition, following the public health perspective, is "areas hosting or having hosted human activities which have produced or might produce environmental contamination of soil, surface or groundwater, air, and 
food chain, resulting or being able to result in human health impacts" [4]. Given this definition, an area affected by a single chemical contamination of a single environmental matrix (e.g., the soil contamination caused by a given pesticide) and a large area with soil, water, air, and food chain contamination by multiple chemicals (e.g., the contamination caused by longterm emissions of a petrochemical complex) can be both considered contaminated sites [2].

According to data collected by the European Environment Agency, Europe has hundreds of thousands of contaminated sites [5], many of them resulting from earlier industrialization and poor environmental management. Past and present activities can cause dispersion and accumulation of countless contaminants, mainly chemicals, to an extent that might affect human health by compromising air quality, altering soil functions, entering the food chain, and polluting groundwater and surfacewater. Typically, but not always, these stressors occur in localized areas near the point sources and affect local communities [6]. This issue is particularly challenging for several reasons: the hazards are very heterogeneous; reliable exposure data are sparse; most associations between industrially contaminated sites and health refer to conditions with multifactorial etiology; and the underlying social, economic and occupational framework is complex. Furthermore, industrially contaminated sites are often located close to urban areas, making exposure patterns more complex [4].

Mining and mineral processing has played a vital part in the history and economy of the Western Balkans. Being abundant with mineral resources, such as copper, chromite, lead, zinc, and antimony, it counts as some of the largest deposits in Europe. Naturally, environmental hotspots in Serbia are, principally, associated with mining, processing and smelting of mentioned metal ores [7-10]. Copper mines and its tailings dam are located close to the eastern coutry boundaries, in Bor, Veliki Krivelj, Cerovo and Majdanpek, while sites contaminated with antimony mining and processing and secondary lead smelter are located at the extreme western spot, bordering Bosnia and Herzegovina: Zajača, Krupanj, Stolice. Coal mining and power plants are surrounding Belgrade: Obrenovac ( 2 power plants), Grabovac (plant ash landfill), Kolubara and Kostolac (Figure 1). Coal was, is and will be most important source of primary energy in Serbia, regarding both the amounts and energy, regardless to any correction of existing reserves estimations. Largest consumers of coal in Serbia are thermal power plants, with consumption of $96 \%$ of total annual production, while remaining part is dried and screened for the industry and open market. Lignite power plants are providing some $60 \%$ of total electricity production, while in winter periods, during which demand for electricity is largest, this contribution increases up to $75 \%$ [10].

The key aim of this paper is to give an insight into the scope of industrial contamination in Serbia, together with types of its sources, focusing on heavy metals and metalloids present in the environment, primarily ambient air.

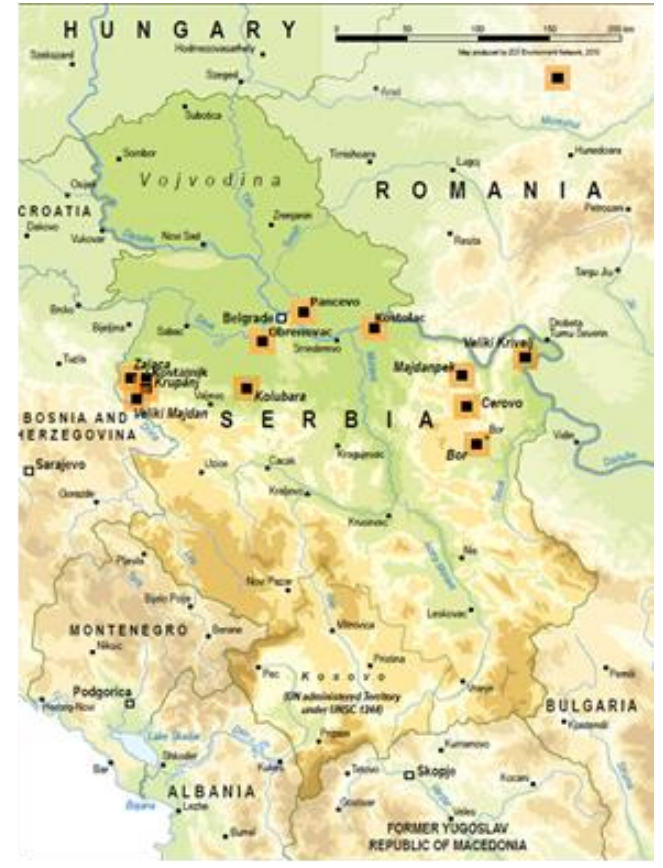

Figure 1 - Location of ICS in Serbia [9]

Specific aim of this paper is to focus on the presence of heavy metals and metalloids in ambient air $\mathrm{PM}_{10}$ particles measured by automatic measuring stations positioned in the vicinity of industrial pollution sources, as atmospheric particles with elevated metals may have serious impact on human health $[11,12]$. Heavy metals are defined as metallic elements that have a relatively high density compared to water [13]. With the assumption that heaviness and toxicity are inter-related, heavy metals also include metalloids, such as arsenic, that are able to induce toxicity at low level of exposure [14].

In recent years, there has been an increasing ecological and global public health concern associated with environmental contamination by these metals. Environmental pollution is very prominent in point source areas such as mining, foundries and smelters, and other metal-based industrial operations [13].

\section{METHODS AND DATA COLLECTION}

In order to present the scope and type of environmental pollution caused by the defined industrial sources, we used the data on regular monitoring implemented by the Serbian Environmental Protection Agency (SEPA), Institute for Mining and metal- 
processing in Bor, Belgrade Institute of Public Health. Continuous measurement of air quality is done through the State network of automatic stations established by the SEPA, part of which are located in Bor, Grabovac, Lazarevac, Veliki Crljeni, and Zajača [15-17]. Key coordinating stakeholder for these measurings is SEPA, while, Belgrade IPH is a legal holder of particular measuring stations within the network [15]. Results of air quality monitoring in Bor are also interpreted in the Annual Report on Air Quality Monitoring produced by the National Institute of Public Health, due to its potential grave public health effect on the exposed population $[18,19]$.

Reasons for choosing the above listed CSs are as follows: Town of Bor suffers complex industrially originating pollution, as both mining for copper ore and smelting is present either in the town, or close to it; Lazarevac (a suburb of the capital city of Belgrade) and Veliki Crljeni are both part of the same coal mining and coal burning power plant complex (lignite mining in Lazarevac, lignite burning power plant in Veliki Crljeni), while Zajača, being a part of inter-connected mining-smelting antimony complex in western Serbia, now hosts a toxic shale landfill of approximately 60.000 tons of weight [20].

The tiniest of all numbered ICSs by its geographic coverage, Zajača village is located on the territory of the town Loznica, with 225 households and 600 inhabitants (Figure 2). It is an example of a typical mining habitat, whose development followed the on-site dynamics of mining-smelting activities. According to the terrain geographical conditions, there were no topographic capacities for the habitat to spread, as it was located in a narrow valley stuck in between steep hills, with River Štira running through it, on its flow towards River Drina (natural border with Bosnia \& Herzegovina). Actually, this was the natural reason disabling better circulation of wind masses, on a terrain suffering continuous ambient air pollution from two defined sources, such as the battery recycling plant and shale landfill, nested on a hill above the village. Hence, population of Zajača has been exposed to longterm contamination generating from the mining-smelting activity, of multiple chemical exposure kind (simultaneous exposure of one population group to contaminants generating from multiple sources) $[20,21]$. Since 2013, SEPA has located its automatic measuring station close to the battery recycling plant in Zajača, with constant, on-line apearence of the data for monitored parameters (Figure 3).

Grabovac, a village close to Obrenovac (coal-fired power plant) hosts a large coal ash landfill, which is the reason why SEPA installed its automatic measuring station there. Besides monitoring $\mathrm{PM}_{10}$ values, this station measures contents of heavy metals, as well.

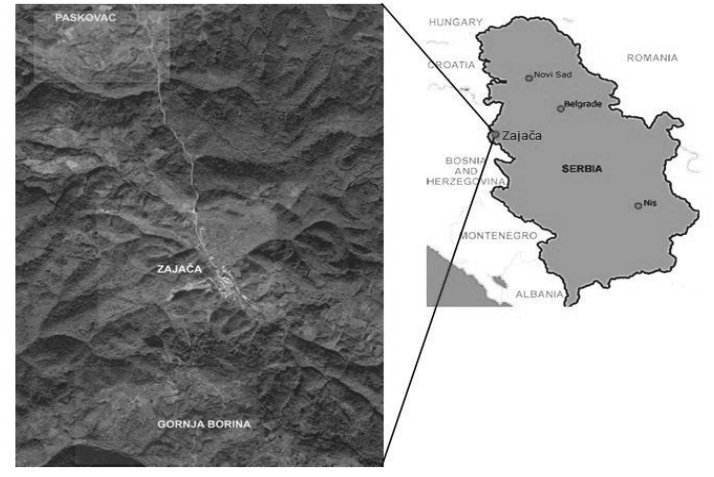

Figure 2 - Location of Zajača mining-smelting complex [17]

\section{RESULTS}

In order to present key public health threats for the population exposed to emissions from diffuse and point sources of industrial contamination, we chose the presence of heavy metals in particulate matter (PM10), due to the fact that both coal and copper ore in Serbia, have substantial naturally occurring contents of heavy metals and metalloids, such as cadmium and arsenic. Results are given for the years 2012 and 2013, as due to the centennial flooding in 2014 all measurement activities were disrupted (Table 1).

Table 1. Heavy metals in air samples $\left(P M_{10}\right)$ at ICSs in Serbia

\begin{tabular}{|c|c|c|c|c|c|}
\hline \multirow{2}{*}{$\begin{array}{l}\text { Geography } \\
\text { cal location }\end{array}$} & \multirow{2}{*}{$\begin{array}{l}\text { Sources of } \\
\text { pollution }\end{array}$} & \multicolumn{2}{|c|}{$2012\left(\mathrm{ng} / \mathrm{m}^{3}\right)$} & \multicolumn{2}{|c|}{$2013\left(\mathrm{ng} / \mathrm{m}^{3}\right)$} \\
\hline & & $\mathrm{Cd}$ & As & $\mathrm{Cd}$ & As \\
\hline Bor & $\begin{array}{l}\mathrm{Cu} \text { mines and } \\
\text { smelting }\end{array}$ & 5.07 & 97.0 & 7.4 & 64.4 \\
\hline Grabovac & $\begin{array}{l}\text { Coal firing ash } \\
\text { landfill }\end{array}$ & 0.44 & 8.7 & 0.2 & 12.9 \\
\hline Lazarevac & Lignite mines & 0.52 & 17.9 & 0.5 & 29.7 \\
\hline $\begin{array}{l}\text { Veliki } \\
\text { Crljeni }\end{array}$ & $\begin{array}{l}\text { Lignite mines \& } \\
\text { power plant }\end{array}$ & 0.1 & 6.4 & 0.3 & 18.5 \\
\hline Zajača & $\begin{array}{l}\text { Abandoned } \mathrm{Sb} \\
\text { mine, } \mathrm{Pb} \\
\text { smelter }\end{array}$ & 27.5 & 6.5 & & \\
\hline $\begin{array}{l}\text { Limit value } \\
\left(\mathrm{ng} / \mathrm{m}^{3}\right)[?]\end{array}$ & & 5.0 & 6.0 & 5.0 & 6.0 \\
\hline
\end{tabular}

Limit values for $\mathrm{PM}_{10}$ contents of arsenic, as defined by the legal act, have been breached at all sampling points, located in the vicinity of industrial hot spots, with the copper mining-smelting complex in Bor leads as the most contaminated urban setting among them. Mean annual value for arsenic in Bor for the year 2012 is more than 16 time higher than the limit value, while for 2013 mean concentration is some tenfold the given limit value [Uredba].

On the other hand, abandoned antimony mining and smelting complex in Zajača, although out of work, is still being depicted as a pollution source, due to the fact that a slag landfill, rich in $\mathrm{As}, \mathrm{Cd}, \mathrm{Sb}$ is situated on 
a hilltop, just above the village occupied by its dwellers. Fact that after the closure of the antimony mine, a battery recycling plant was installed on-site, justifies the occurence of cadmium, primarily in ambient air particles. The only automatic measuring station of the SEPA on that location belongs to the
National Network of automatic stations (AMSs), and was installed on-site in 2013, with specific focus on lead concentration in PM10 particles, parallel to innitial human biomonitoring activities, with measuring lead in blood of exposed children (Figure 3) $[15,17,20]$.

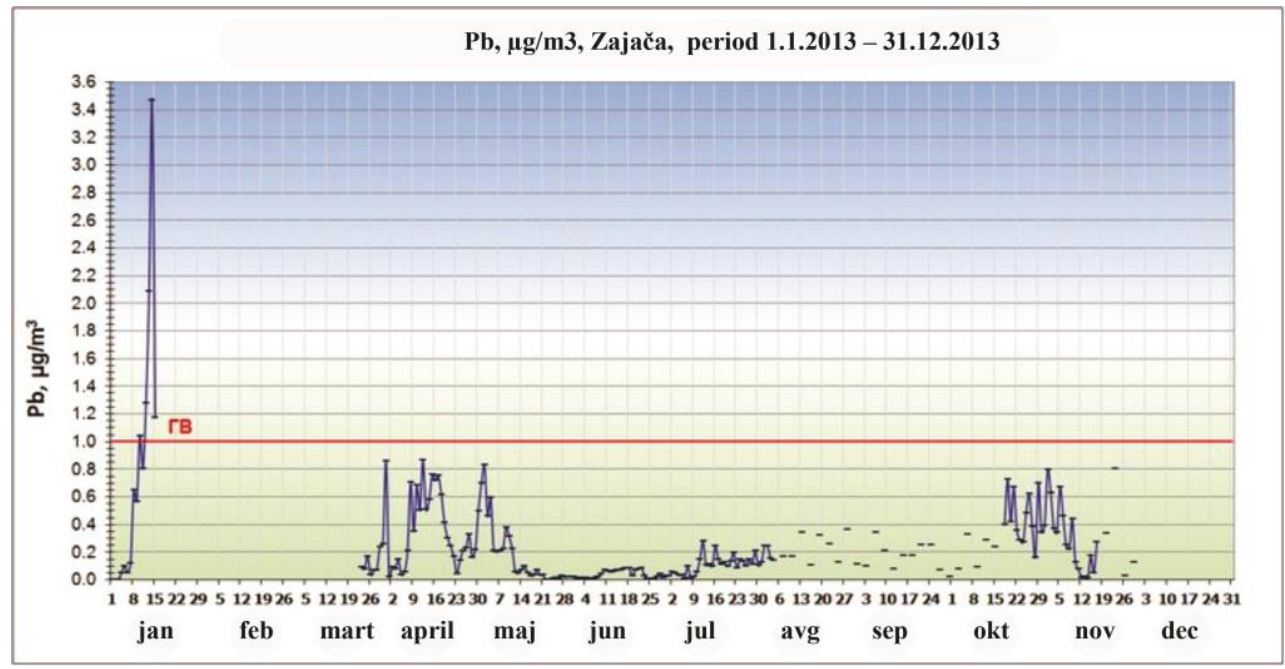

Figure 3 - Ambient air Pb concentration, SEPA [17]

\section{DISCUSSION}

\subsection{Arsenic in copper ore}

Contents of heavy metals and arsenic in $\mathrm{PM}_{10}$ is ususlly high in the vicinity of industrial sources of pollution. High concentration of arsenic in copper ore that is exploited in Bor and surrounding mines is an often proven quantitative fact, as mentioned in earlier findings [21, 22, 23]. The point that arsenic in ambient air $\mathrm{PM}_{10}$ is continuously monitored in Bor, and that its concentration is yet not dropping down, without any thorough investigation into the health impacts of exposure of domicile population, is a worrying sign. Until now, the only case-study providing data on human biomonitoring in population exposed to arsenic, was a study aiming to provide evidence of cardiological effects of naturally occuring arsenic in groundwater in Zrenjanin, Serbia [24], with no such a study provided for the exposed population of Bor.

\subsection{Arsenic in coal and coal ash}

Coal combustion is one of the main anthropogenic sources of toxic trace element emissions to the environment. Various species and oxidation states of the trace elements released from power stations may determine their ultimate environmental fate and health impacts [25]. Coal ash is the waste that is left after coal is combusted (burned). It includes fly ash (fine powdery particles that are carried up the smoke stack and captured by pollution control devices) as well as coarser materials that fall to the bottom of the furnace. Most coal ash comes from coal-fired electric power plants [26]. When speeking of coal ash in Serbia, it is estimated that, during last decade, in Central Serbia, some 5.5 million tons of ash were separated, i.e. 62.5 tons per square kilometer or 0.77 tons per inhabitatnt, listing Serbia at the top, when coal ash production is the case, proportionally speaking [27]. Three of our sites with mean annual arsenic values above the limits given by the Decree are linked to coal mining, coal firing and deposition of waste produce of combustión (coal ash deposition site). In Grabovac, hosting coal ash disposal site for coal brought from Kolubara lignite mines, arsenic in PM10 mean annual value was increased for $45 \%$ of the limit value $\left(6.0 \mathrm{ng} / \mathrm{m}^{3}\right.$ vs. 8.7 $\mathrm{ng} / \mathrm{m}^{3}$ ), while in 2013 it was more tan a two-fold limit value $\left(12.9 \mathrm{ng} / \mathrm{m}^{3}\right)$. Fact is that directly next to the disposal site there are no dwellings, but some 3000 of inhabitants at the village Grabovac live in the vicinity, within the $3 \mathrm{~km}$ diameter from it [27].

\subsection{Antimony mining and lead battery recycling}

The village of Zajača is situated in western Serbian Macva County, with a population of barely 600, some 140 kilometers from the capital, Belgrade. It comprises solely of metallurgy industrial complex surrounded with residential homes of the employees. The battery recycling facility is located in the village's center in a steep valley of the Jadar River, being geographically isolated.

Prior to opening of the battery recycling plant, this ICS hosted an antimony mining-smelting complex, for decades. Arsenic was used in production of refined antimony, in the smelting process, becoming a 
continuous element of the toxic slag deposition, situated at the top of the hill above Zajača [20,28]. Arsenic and cadmium were monitored at the ICS of Zajača (Mačva District) only in 2012, in our study. Mean anual concentration for cadmium at the site is a fivefold the value given by the regulation $\left(5.0 \mathrm{ng} / \mathrm{m}^{3}\right)$ [29]. On the other hand, mean value for arsenic is just slightly elavated. This numbers could be explained by the fact that battery recycling waste was deposed at the deposition site more recently, while use of arsenic in antimony smelting has a far more historic background [28].

Lead in ambient air $\mathrm{PM}_{10}$ was monitored in connection with the lead production process at the battery recyclimg plant in Zajača, by the AMS installed by the SEPA [17]. As Figure 3 shows, Pb concentration oscilates due to production discontinuity, with peaks above the limit value of $0.5 \mu \mathrm{g} / \mathrm{m}^{3}$ during months March - May 2013, a break in production in the period June to October 2013, when production of metallic lead was shortly revived, until it finally stoped in November, due to factory's closure. Similar to this monitoring, a study was performed in Zajača in the period 1998-1999, when a significant correlation was reached between daily production of lead and $\mathrm{Pb}$ in $\mathrm{PM} 10$, measured next to the plant [30].

\section{CONCLUSIONS}

Although Republic of Serbia is a signatory of Parma Declaration in 2010 at the 5th Ministerial Conference for Environment and Health in Parma, Italy, adopted CEHAP (Children's Environment and Health Action Plan) as its national legal act, both focusing on environmental health challanges for children's health and human biomonitoring as a tool for its monitoring [33], no further steps were made since in implementation of these international binding obligations [31, 32]. Republic of Serbia, with its health sector in a leading role, needs to organize and adopt human biomonitoring as a key public health measure, especially for the vulnarable population groups living close to recognized ICSs. Reason for such an urgent need in implementing this kind of preventive measures is in the nature of most highly toxic substances to which these vulnerable groups are being exposed, to be absorbed easilly by pregnant mothers, and transfered transplacentary to the offspring, making severe organic damage to the unborn child.

\section{REFERENCES}

[1] Molina M J \& Molina LT. Megacities and Atmospheric Pollution; J Air Waste Manage. Asso., Vol. 54, No.6: 644-680, 2004.

[2] Pirastu R, Pasetto R, Zona A, Ancona C, Iavarone I, Martuzzi M, et al. The Health Profile of Populations
Living in Contaminated Sites: Sentieri Approach. Journal of Environmental and Public Health, Volume 2013, 2013.

[3] European Environment Agency, "Overview of economic activities causing soil contamination in some WCE and SEE countries (pct. of investigated sites)," 2013, Available at: http://www.eea.europa.eu/dataand-maps/figures/overview-of-economicactivitiescausing-soil-contamination-in-some-wce-andseecountries-pct-of-investigated-sites

[4] World Health Organization (WHO), Contaminated Sites and Health. Report of Two WHO Workshops: Syracuse, Italy, 18 November 2011; Catania, Italy, WHO Regional Office for Europe, Copenhagen, Denmark, 21-22 June 2012. Available at: http://www.euro.who.int/_data/assets/pdf_file/000 3/186240/e96843e.pdf?ua=1

[5] European Environment Agency, "Progress in management of contaminated sites (CSI 015) -Assessment published Aug 2007," http://www.eea.europa.eu/data-and-maps/indicators/progress-in-management-of-contaminated-sites/progress-in-management-of-contaminated-1 .

[6] Martuzzi M, Pasetto R, Martin-Olmedo P. Industrially contaminated sites and health. J Environ Public Health 2014; 2014.

[7] Mioč UB, Colomban Ph, Sagon G, Stojanović M, Rosić A. Ochre Decor and Cinnabar Residues in Neolithic Pottery from Vinča, Serbia. Journal of Raman Spectroscopy, Vol.35, No.10: 843-846, 2004.

[8] Petković S, Traces of Roman Metallurgy in Eastern Serbia; Journal of Mining and Metallurgy, Vol.45, No.2: 187-196, 2009.

[9] Jovanović B. Beginning of the Metal Age in the Central Balkans According to the Results of the Archeometallurgy; Journal of Mining and Metallurgy Vol.45, No.2 B: 143-148, 2009.

[10] "Mining and Environment in the Western Balkans", pdf, 2009, Ed Christina Stuhlberger: UNEP, 77-82, 2009. [Internet], Available at http://envsec.grid.unep.ch/docs/miningbalkans_scre en.pdf

[11] Liu L, Rudy TD, Dalipaj M,et al. Effect of indoor, outdoor and personal exposure to particulate air pollution on cardiovascular physiology and systematic mediators in seniors. J Occup Environ Med, Vol. 51: 1088-1098, 2009.

[12] Mavroidis I, Chaloulakou A. Characteristics and expected health implications of annual $\mathrm{PM}_{10}$ concentrations in Athens, Greece. Intern. J. of Environ. and Poll., Vol. 41, No.1/2: 124-139, 2010.

[13] World Health Organization (WHO), Health risks of heavy metals from long-range transboundary air 
pollution, WHO Regional Office for Europe, ISBN 9789289071796 , available at http://www.euro.who.int/_data/assets/pdf_file/0007/78649/E91044. pdf , 2007.

[14] Young-Seoub Hong, Ki-Hoon Song, Jin-Jong Chung. Health Effects of Chronic Arsenic Exposure; J Prev Public Health, Vol.47, No.5: 245-252, 2014.

[15] Decree on defining Programme on Air Quality Control within the State Network ("Official Gazette of $R S$ ” No. 58/11).

[16] Annual report on the air quality status in Republic of Serbia in 2012; Serbian Agency for Environment Protection, Ministry of energy, development and environment protection, Available at: www.sepa.gov.rs/download/VAZDUH2012.pdf, 2013.

[17] Annual report on the air quality status in Republic of Serbia in 2013; Serbian Agency for Environment Protection, Ministry of energy, development and environment protection (2014). Available at: www.sepa.gov.rs/download/VAZDUH2013.pdf

[18] "Urban air pollution in Serbia in 2012 monitored by the Network of Institutes of Public Health", Institute of public health of Serbia "Dr Milan Jovanović Batut" Matić B. Available at: www.batut.org.rs/download/izvestaji/higijena/Zagadjenost\%20vazduh a\%20u\%20mrezi\%20urbanih\%20stanica\%202012.p df, 2013

[19] "Urban air pollution in Serbia in 2013 monitored by the Network of Institutes of Public Health", Institute of public health of Serbia "Dr Milan Jovanović Batut" Matić B. Available at: www.batut.org.rs/download/zvestaji/higijena/izvestajVazduh2013.pdf, 2014

[20] "Environmental health indicators in Republic of Serbia in 2013", Matić B, Jovanović D, Knežević T, Dejanović S, Rakić U.; Institute of public health of Serbia "Dr Milan Jovanović Batut" Available at: http://www.batut.org.rs/download/izvestaji/Zdravstv eni\%20indikatori\%20zivotne\%20sredine\%202013.p df, 2014.

[21] Šerbula S. Air quality in Bor and its surroundings; 17th Scientific Professional Conference on Natural Resources and Environmental Protection (2009); Book of Proceedings: 9-16. ISBN 978-86-80987-576, Available at: http://www.eco-ist.rs/Zbornik\%20radova\%20EkoIst\%202009.pdf

[22] Mihajlovic I, Štrbac N, Nikolić D, Živković Z. Potential metallurgical treatment of copper concentrates with high arsenic contents. J S Afr I Min Metall Vol.111, No.6: 409-416 Available at: https://www.saimm.co.za/Journal/v111n06p409.pdf

[23] Kovačević R, Jovašević-Stojanović M, Tasić V, Milošević N, Petrović N, Stanković S. et al. Preliminary analysis of levels of arsenic and other metalic elements in $\mathrm{PM}_{10}$ sampled near copper smelter Bor
(Serbia); CI\&CEQ Vol. 16, No.3: 269-279. DOI 10.2298/CICEQ091225049K, 2010.

[24] Jovanovic D, Paunovic K, Manojlovic D, Jakovljevic $B$, Rasic-Milutinovic Z, Dojcinovic B. Arsenic in drinking water and acute coronary syndrome in Zrenjanin municipality, Serbia. Environmental Research Vol. 117, No.1: 75-82, DOI: 10.1016/j.envres.2012.04.016, 2012.

[25] Pushan Shah, Vladimir Strezov, Chris Stevanov, Peter F. Nelson; Speciation of Arsenic and Selenium in Coal Combustion Products. Energy Fuels, Vol. 21, No.2: 506-512, 2007.

[26] U.S. Environmental Protection Agency, Office of Solid Waste and Emergency Response, Office of Resource Conservation and Recovery. "Human and Ecological Risk Assessment of Coal Combustion Wastes.” Draft EPA document. Pp 2-4, April 2010. Available at: http://earthjustice.org/sites/default/files/library/repor ts/epa-coal-combustion-waste-risk-assessment.pdf

[27] Nišić D, Knežević D, Pantelić U, Tomašević A. Risk Classification of "Nikola Tesla-B" Power Plant's Ash disposal Site. TEHNIKA - Rudarstvo, Geologija $i$ Metalurgija, Vol. 66, No.5: 769-776, 2015.

[28] Kamberović Ž., Korać M, Andjić Z, Štulović M, Kovačević T, Vujović A, Ilić I. Conceptual design for treatment of mining and metallurgical wastewaters which contain arsenic and antimony, Metall.Mater Eng. Vol 18(4) : 321-331, 2012.

[29] Decree on the air quality monitoring conditions and requested air quality ("Official Gazette of the $R S^{\prime \prime}$, No. 11/2010; 63/2013)

[30] Matić B, Gojković M, Separović N. Influence of Lead in Suspended Particles on Blood Lead Levels of Children Living in the Vicinity of a Secondary Lead Smelter. 1st International WeBIOPATR Workshop, Beograd, Serbia 22-25th May 2007. Book of Extended Abstracts, Eds. M.Jovasevic-Stojanovic, A.Bartonova: 124-126. ISBN 978-86-7306-086-6, 2007.

[31] Parma Declaration on Environment and Health; Fifth Ministerial Conference on Environment and Health "Protecting children's health in a changing environment" Parma, Italy, 10-12 March 2010 Available at: http://www.euro.who.int/_data/assets/pdf_file/0011/78608/E93618.pdf

[32] Children's Environment and Health Action Plan in Republic of Serbia, for the period 2009-2019, ("Official Gazette of $R S^{\prime \prime}$ No. 83/2009).

[33] World Health Organization (WHO), Human biomonitoring: facts and figures. WHO Regional Office for Europe, Copenhagen, Denmark, 2015. Available at: http://www.euro.who.int/_data/assets/pdf_file/0020/276311/Human-biomonitoringfacts-figures-en.pdf 


\section{REZIME}

\section{INDUSTRIJSKI KONTAMINIRANI LOKALITETI U SRBIJI KAO POTENCIJALNA JAVNO- ZDRAVSTVENA PRETNJA ZA IZLOŽENU POPULACIJU}

Rudarstvo i prerada metala je još uvek vitalni izvor prihoda u Srbiji, zahvaljujući značajnim mineralnim nalazištima bakra, olova, cinka, antimona. Rudnici i topionica bakra locirani su na istoku zemlje: Bor, Veliki Krivelj, Cerovo, Majdanpek. Napušteni rudarsko-topionički kompleks antimona i fabrika za reciklažu akumulatora blizu su zapadne državne granice: Zajača, Krupanj, Stolice. Rudnici uglja $i$ termoelektrane, okružuju Beograd: Obrenovac (2 termoelektrane), Grabovac (pepelište TENT), Kolubara $i$ Kostolac. Glavni cilj rada je fokusirati se na potencijalne javno-zdravstvene pretnje poreklom od industrijskih zagađenja u Srbiji. Usled činjenice da su teški metali $(\mathrm{Pb}, \mathrm{Cd})$ i metaloidi (As) prirodno prisutni u rudama i površinskom sloju tla, njihovo prisustvo u PM 10 frakciji ambijentalnog vazduha, predstavlja značajan javno-zdravstveni problem, u blizini industrijski kontaminiranih lokaliteta. Izvor podataka su Agencija za životnu sredinu Srbije, Institut za rudarstvo i metalurgiju Bor, Gradski zavod za javno zdravlje Beograd, koji čine integralni deo sistema za kontinuirani monitoring kvaliteta vazduha u sklopu Državne mreže automatskih mernih stanica. Koncentracije arsena u PM10 česticama ekstremno su iznad dozvoljenih vrednosti u Boru i Lazarevcu, dok koncentracije kadmijuma u Boru nisu značajnije povećane.

U Srbiji nije usvojena regulativa kojom se omogućava kontinuirano i institucionalizovano praćenje štetnih uticaja iz životne sredine nan a njima izložene osetljive populacione grupe, iako su jasno definisane visoke koncentracije polutanata jasni pokazatelj da takve mere treba što pre preduzeti.

Ključne reči: industrijski kontaminirani lokalitetijavno zdravlje, $\mathrm{As}, \mathrm{Cd}, \mathrm{Pb}$ 